\title{
Simulation Results: Optimization of Contact Ratio for Interdigitated Back-Contact Solar Cells
}

\author{
Vinay Budhraja, ${ }^{1,2}$ Srinivas Devayajanam, ${ }^{2}$ and Prakash Basnyat ${ }^{2}$ \\ ${ }^{1}$ University of Missouri at Kansas City, Kansas City, MO, USA \\ ${ }^{2}$ New Jersey Institute of Technology, Newark, NJ, USA \\ Correspondence should be addressed to Vinay Budhraja; vbudhraja@gmail.com
}

Received 27 July 2017; Revised 18 September 2017; Accepted 25 September 2017; Published 14 December 2017

Academic Editor: Yanfa Yan

Copyright @ 2017 Vinay Budhraja et al. This is an open access article distributed under the Creative Commons Attribution License, which permits unrestricted use, distribution, and reproduction in any medium, provided the original work is properly cited.

\begin{abstract}
In the fabrication of interdigitated back contact (IBC) solar cells, it is very important to choose the right size of contact to achieve the maximum efficiency. Line contacts and point contacts are the two possibilities, which are being chosen for IBC structure. It is expected that the point contacts would give better results because of the reduced recombination rate. In this work, we are simulating the effect of contact size on the performance of IBC solar cells. Simulations were done in three dimension using Quokka, which numerically solves the charge carrier transport. Our simulation results show that around $10 \%$ of contact ratio is able to achieve optimum cell efficiency.
\end{abstract}

\section{Introduction}

IBC structure for silicon solar cells is a promising technology for photovoltaics, and it is proven that it offers higher efficiency than other structures. Recently, a research paper published in Nature Energy (by Yoshikawa et al. [1]) has reported cell efficiency above $26 \%$ on IBC structure. In the past, an efficiency of above 25\% [2-4], above 24\% [5], and above $23 \%[6,7]$ based on IBC structure have also been reported by different research groups. Moreover, solar cells based on IBC structure have been produced commercially [8-11]. There are optical and electrical advantages associated with IBC structure [12], which makes it the best design for silicon solar cells.

IBC structure consists of an array of alternate n- and p-diffused regions or an array of alternate emitter and back surface field (BSF) regions on the back surface. IBC solar cells are fabricated with different dimensions of emitter and BSF [13]. The emitter of IBC solar cells is chosen not only wider than BSF to increase short circuit current [14] but also it is optimized with respect to BSF to reduce the effect of electrical shading or EQE losses [15]. The contact opening of emitter and BSF is another important parameter in the designing of IBC solar cells because it is responsible for power [16] and series resistance loss [17]. According to Meier and Schroder [18], the selection of contact size depends on the current transfer length. The current transfer length depends on contact resistivity and sheet resistance; its impact on the parameters of solar cells is not fully understood. The current transfer length is defined as a distance over which the current transfers from a metal contact to a diffused region. There are various articles in the literature [19-22], which simulated the IBC solar cells at different dimensions of emitter and BSF but they did not optimize the dimensions of contact with respect to emitter and BSF, and contact size was chosen irrespective of the dimensions of emitter and BSF. However, there are very few articles in the literature, which simulated the impact of contact size on contact resistance [23], sheet resistance [24], saturation current density [25], and leakage current density [26].

In this paper, we are simulating the IBC structure of silicon solar cell in three dimension with respect to the contact ratio. The contact ratio is defined as the ratio of width of contact opening to the width of emitter and BSF. For modeling, we used a software tool called Quokka, which is able to simulate silicon solar cell devices in $1 \mathrm{D} / 2 \mathrm{D} / 3 \mathrm{D}$ [27]. The back surface of IBC solar cell looks like ZEBRA crossing which is symmetric around one emitter and BSF 


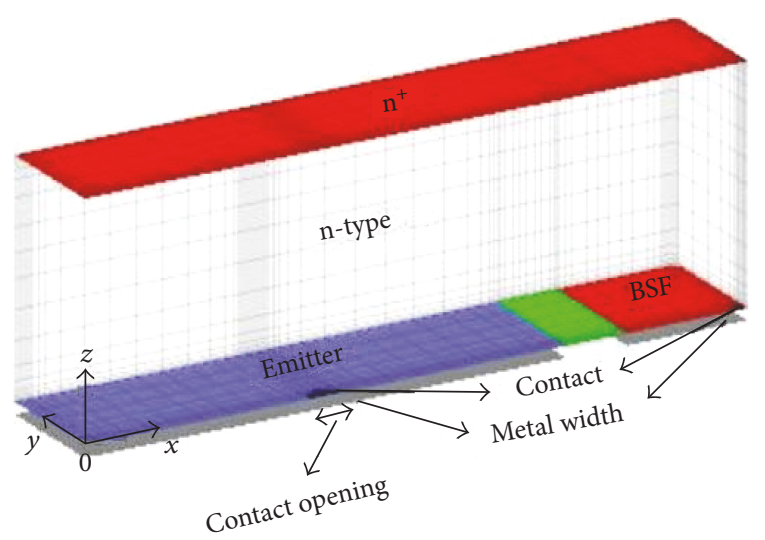

FIGURE 1: Unit cell of IBC solar cells.

[28] that is why the simulation of unit cell, which consists of half emitter and BSF, resembles the behavior of a complete IBC structure $[15,16,20,24]$. In this work, we are simulating the unit cell of IBC structure in three dimension. For the metal contacts, we selected line and point contacts on emitter and BSF.

\section{Simulation Details}

We simulated the unit cell (as shown in Figure 1) of IBC solar cells in three dimension using Quokka. Quokka is a simulation tool for solar cells, the results of which are well comparative with SANTARUS $[29,30]$. The unit cell of IBC has half width of emitter, half width of BSF, and the gap between emitter and BSF. For the bulk, we selected n-type silicon because it has high lifetime and diffusion length $[31,32]$. It is desired to have high diffusion length for better working of IBC solar cells $[13,16]$. Front surface is doped with phosphorous to have the effect of front surface field, which reflects the minority carriers to the bulk. Emitter is doped with boron and BSF is doped with phosphorous. The gap between emitter and BSF is considered as being well passivated with $\mathrm{SiO}_{2}$.

For the contacts to emitter and BSF, we selected line and circle (point) contact as shown in Figures 2(a) and 2(b), respectively. In this work, we simulated the effect of point and line contacts on the performance of IBC solar cells.

Table 1 shows the values of input parameters, which were taken for the simulation of IBC solar cells. The input parameters like widths of emitter and BSF [5, 13, 33, 34], saturation current densities $[16,35,36]$, and sheet resistances $[13,16,24,37]$ were selected according to the fabricated designs published in research articles. The width of contacts were varied from $8 \mu \mathrm{m}$ to $80 \mu \mathrm{m}$ to get different combinations of the ratio for contact openings. In the case of point contact, the width of contact is the diameter. The contact ratio (CR) is calculated with respect to the dimensions of emitter and BSF and is explained in

$$
\mathrm{CR}=\frac{\text { (contact } \text { opening } \times \text { number } \text { of contacts })}{(\text { width of emitter }+ \text { width of BSF })}
$$

\section{Simulation Results}

3.1. Point Contact. The radius of point contacts varied from $8 \mu \mathrm{m}$ to $80 \mu \mathrm{m}$ which gives contact ratio between $3.2 \%$ and $32 \%$. Light $J-V$ characteristics were calculated under the illumination of the front side. Figure 3 shows the light $J-V$ characteristics between the voltage ranges from $100 \mathrm{mV}$ to $700 \mathrm{mV}$. Fill factor reduces at lower contact ratios and it becomes stable as the contact ratio increases. This happens due to the increase in series resistance as shown in Figure 4. Fill factor dependence on series resistance is given in [38]

$$
\mathrm{FF}_{\mathrm{s}}=\mathrm{FF}_{0}\left(1-1.1 \frac{R_{\mathrm{s}} I_{\mathrm{sc}}}{V_{\mathrm{oc}}}\right),
$$

where $\mathrm{FF}_{0}$ is the fill factor not affected by series resistance, $R_{\mathrm{s}}$ is the series resistance, $I_{\mathrm{sc}}$ is the short circuit current, and $V_{\text {oc }}$ is the open circuit voltage.

The contact size affects the contact resistance [39], which further affects the fill factor [40]. This reason is related to the fact that contact size changes the current transfer length, which affects contact resistivity. Contact resistivity is dependent on doping density, and it prevents the formation of good ohmic contact because of surface state Fermi level pinning except the heavily doped regions in semiconductor.

Figure 4 shows the variation of $R_{\mathrm{s}}$ and $V_{\mathrm{oc}}$ with respect to contact ratio. The dependence of $V_{\mathrm{oc}}$ on solar cell is given as in [38]

$$
V_{\mathrm{oc}}=\frac{n k T}{q} \ln \left(\frac{I_{\mathrm{L}}}{I_{0}}+1\right),
$$

where $I_{\mathrm{L}}$ is the light-induced current, $I_{0}$ is the saturation current, $n$ is the ideality factor, $k$ is Boltzman's constant, $T$ is temperature, and $q$ is charge.

Suns $V_{\text {oc }}$ is calculated with respect to total current generation at 1 Sun. Suns $V_{\text {oc }}$ provides the light current-voltage characteristics of the diode without the effects of series resistance [38]. This is calculated as given in [41]

$$
\text { Suns } V_{\mathrm{oc}}=\frac{k T}{q} \ln \left(\frac{J_{\mathrm{ph}, 1 \text { Sun }}}{J_{0}+J_{0, \text { base }}}+1\right) \text {, }
$$

where $J_{\mathrm{ph}, 1 \text { Sun }}$ is the total generation at 1 Sun (we considered it to be $40 \mathrm{~mA} / \mathrm{cm}^{2}$ ) and $J_{0, \text { base }}$ is the saturation current in the base region but it does not represent the recombination with ideality factor.

In normal $V_{\text {oc }}$, the effects of ideality factor and series resistance are considered but in Suns $V_{\text {oc }}$ these two are ignored.

Suns $V_{\text {oc }}$ (upper curve) decreases with the increase in contact ratio. This happens because of the change in saturation current density [25] which is true as expected because the recombination will increase with the increase in contact ratio (as shown in Figure 5(a)). However, the behavior of $V_{\text {oc }}$ (lower curve in Figure 4) which is calculated from Figure 3 is different. Although $V_{\text {oc }}$ does not show much change with respect to contact ratio, $V_{\text {oc }}$ values decrease at the contact ratio below $15 \%$ and the $R_{\mathrm{s}}$ values increase below 


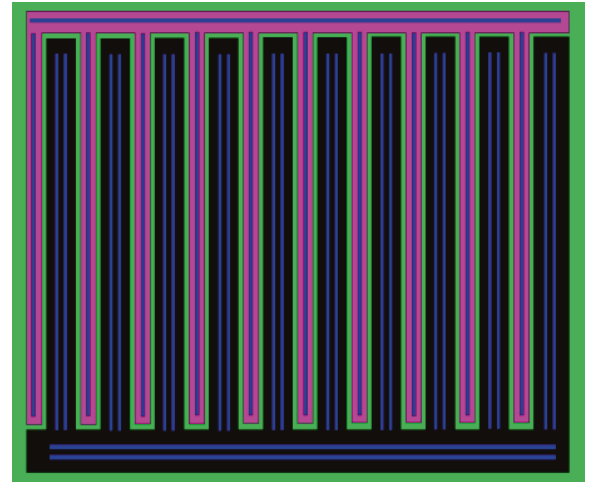

(a)

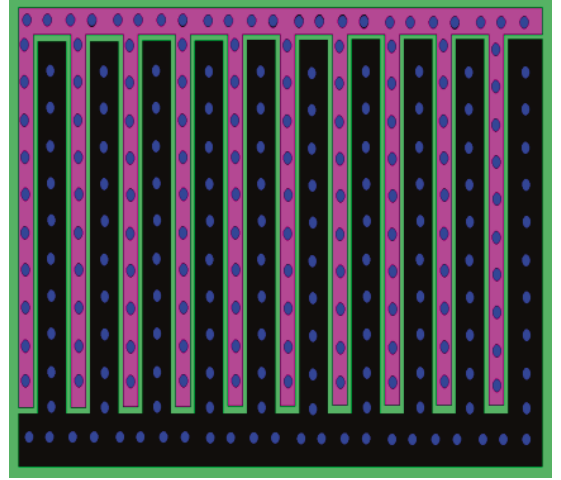

(b)

FIGURE 2: Backside view of IBC solar cell with (a) line contact and (b) point contact. Colored regions are as follows: black, emitter; pink, BSF; green, gap; and blue, contact.

$15 \%$. This happens because of the decrease in current transfer length [18]. Above 15\%, there is a minor increase in $V_{\text {oc }}$ but $R_{\mathrm{s}}$ is stable. Above $10 \%$, the slight decrease in $R_{\mathrm{s}}$ is responsible for the change in $V_{\mathrm{oc}}$ [42]. This explanation supports the behavior of maximum power $\left(P_{\max }\right)$ which is shown in Figure 6. $P_{\max }$ changes its behavior around contact ratio of $10 \%$. Below $10 \%, P_{\max }$ increases due to the decrease in series resistance and above $10 \% P_{\max }$ decreases due to the increase in recombination, around which the Suns $V_{\text {oc }}$ (contact ratio between $10 \%$ and $32 \%$ ) also decreased. In the range between $10 \%$ and above, the maximum voltage coming out from the solar cells also decreased.

Figure 5 shows the variation due to recombination mechanism in emitter and BSF. The recombination in Figure 5(a) is the actual recombination without any normalization. The left recombination is in the emitter and the right recombination is in the BSF. The light $J-V$ characteristics in Quokka is calculated according to [27]

$$
\begin{aligned}
J^{\text {light }}= & A_{\text {inner }}^{\text {light }} J_{\text {inner }}^{\text {light }}+A_{\text {inner }}^{\text {dark }} J_{\text {inner }}^{\text {dark }}+A_{\text {emitter }} J_{\text {emitter }}^{\text {dark }} \\
& +A_{\mathrm{BSF}} J_{\mathrm{BSF}}^{\text {dark }}+A_{\text {edge }} J_{\text {edge }}^{\text {dark }}
\end{aligned}
$$

where $A$ denotes the part of the area represented by unit cell and $J_{\text {emitter }}$ and $J_{\mathrm{BSF}}$ are current densities inside the emitter and BSF, respectively.

The current densities in the emitter and BSF can be represented by the two diode models of solar cells $[43,44]$ as represented in the following:

$$
\begin{aligned}
J= & J_{01}\left\{\exp \left(\frac{q\left(V-I R_{\mathrm{s}}\right)}{k T}\right)-1\right\}+J_{02}\left\{\exp \left(\frac{q\left(V-I R_{\mathrm{s}}\right)}{2 k T}\right)-1\right\} \\
& +\left(\frac{V-I R_{\mathrm{s}}}{R_{\mathrm{sh}}}\right)-J_{\mathrm{L}}
\end{aligned}
$$

where $J_{01}$ and $J_{02}$ are saturation current densities in quasineutral and depletion region. $J_{\mathrm{L}}$ is the light-induced current. The first component in (4) is due to diffusion and the second component is due to recombination.

Figure 5(a) shows the variation of recombination in emitter (left) and BSF (right) with respect to the contact ratio. The contacts on emitter and BSF accounts for around 6\% $[16,17]$ of recombination losses in solar cells. These recombination losses reduce short circuit current and cell efficiency. Figure 5(b) shows the component of recombination current due to the contacts in emitter and BSF. Left recombination current is in emitter and right recombination current is in BSF. There is a continuous increase in recombination (Figure 5(a)) and a continuous decrease in recombination current (Figure 5(b)) with respect to the contact ratio. The recombination increases gradually below $10 \%$ of contact ratio and increases suddenly above $10 \%$ of contact ratio. However, it does not show much effect in the case of recombination currents due to the contacts especially in the emitter region. This happens because the emitter in IBC structure is always wider than the BSF region. One can reduce recombination by reducing contact pitch. Contact pitch affects cell parameters and maintain tradeoff between recombination and resistive losses [45]. Moreover, widely spaced contacts are responsible for ohmic losses and degrade the efficiency of solar cells [46].

3.2. Line Contact. In the second part of simulation, we used rectangular shape for contact and repeat the same calculations we performed in part I. Because the width of contact was very small that is why we called it line contact. Line contact covers more area than point contact, which affects recombination. The width of line contacts varied from $8 \mu \mathrm{m}$ to $80 \mu \mathrm{m}$.

Figure 7 (main figure) shows the variation of light $J$ - $V$ characteristics with respect to different contact ratios. As the contact ratio decreases, the curve moves toward the high values of $V_{\text {oc }}$. The variation in $J-V$ curves in the case of line contact are less than the case of point contact. In Figure 7 (inset figure), the lower values of voltages are excluded to closely observe the variation in $J-V$ characteristics. With the decrease in contact ratio, the cell parameters like $V_{\mathrm{oc}}$, efficiency, and fill factor increase in the case of line contact. In the case of line contact, we are the not plotting the variation of maximum power because it is clear from Figure 7 that the maximum power which comes out from a solar cell will decrease with contact ratio.

Figure 8 shows the variation of $R_{\mathrm{s}}$, Suns $V_{\mathrm{oc}}$, and $V_{\mathrm{oc}}$ (calculated from Figure 7 ) with respect to contact ratio. 
TABLE 1: Simulation parameters.

\begin{tabular}{|c|c|}
\hline Parameters & \\
\hline \multicolumn{2}{|l|}{ (i) Unit cell dimensions } \\
\hline Cell thickness & $180 \mu \mathrm{m}$ \\
\hline Half width in $x$ direction & $550-1050 \mu \mathrm{m}$ \\
\hline Width in $y$ direction & $100 \mu \mathrm{m}$ \\
\hline \multicolumn{2}{|l|}{ (ii) Front surface } \\
\hline Boundary type & Conductive \\
\hline Sheet resistance & $120-140 \Omega / \square[13,16,24,37]$ \\
\hline Doping type & n-type \\
\hline $\begin{array}{r}J_{\text {oFront }} \\
\text { (iii) Bulk }\end{array}$ & $1.00 E-13 \mathrm{~A} / \mathrm{cm}^{2}[16,35,36]$ \\
\hline Doping type & n-type \\
\hline Resistivity & $3 \Omega \cdot \mathrm{cm}$ \\
\hline Lifetime & $3000 \mu \mathrm{s}$ \\
\hline \multicolumn{2}{|l|}{ (iv) Rear (emitter/BSF) } \\
\hline \multicolumn{2}{|l|}{ (a) Emitter } \\
\hline Contact opening: contact shape & Line/circle \\
\hline Half width in $x$ direction & $4-40 \mu \mathrm{m}$ \\
\hline Contact pitch in $x$ direction & $200 \mu \mathrm{m}$ \\
\hline Number of contacts & 4 \\
\hline Metal width (shown in Figure 1) & Same as emitter width \\
\hline Contact position & Aligned \\
\hline Emitter: shape & Line \\
\hline Half width & $400-800 \mu \mathrm{m}[5,13,33,34]$ \\
\hline Sheet resistance & $60-80 \Omega / \square[13,16,24,37]$ \\
\hline Contacted region: $J_{\mathrm{o}}$ & $6 E-13 \mathrm{~A} / \mathrm{cm}^{2}[16,35,36]$ \\
\hline Contact resistivity & $1 E-4 \Omega \cdot \mathrm{cm}^{2}$ \\
\hline $\begin{array}{l}\text { Noncontacted region: } J_{\mathrm{o}} \\
\text { (b) Gap }\end{array}$ & $2.7 E-14 \mathrm{~A} / \mathrm{cm}^{2}[16,35,36]$ \\
\hline $\begin{array}{l}\text { Non-contacted region: } J_{\mathrm{o}} \\
\text { (c) BSF }\end{array}$ & $1 E-14 \mathrm{~A} / \mathrm{cm}^{2}$ \\
\hline Contact opening: contact shape & Line/circle (centrally located) \\
\hline Half width in $x$ direction & $4-40 \mu \mathrm{m}$ \\
\hline Contact pitch in $x$ direction & $100 \mu \mathrm{m}$ \\
\hline Number of contacts & 1 \\
\hline Metal width (shown in Figure 1) & Same as BSF width \\
\hline Contact position & Centrally located \\
\hline BSF: shape & Line \\
\hline Half width & $100-200 \mu \mathrm{m}[5,13,33,34]$ \\
\hline Sheet resistance & $30-50 \Omega / \square[13,16,24,37]$ \\
\hline Contacted region: $J_{\mathrm{o}}$ & $3.15 E-13 \mathrm{~A} / \mathrm{cm}^{2}[16,35,36]$ \\
\hline Contact resistivity & $1 E-4 \Omega \cdot \mathrm{cm}^{2}$ \\
\hline Noncontacted region: $J_{\mathrm{o}}$ & $5 E-14 \mathrm{~A} / \mathrm{cm}^{2}[16,35,36]$ \\
\hline
\end{tabular}

Unlike point contact, the variation in $V_{\mathrm{oc}}$ does not change around any specific value of contact ratio. This happens because line contact covers more area than point contact. That is why the variation with respect to the width of line contact is negligible. There is a sudden decrease in series resistance from $0 \%$ to $10 \%$ of contact ratio and it continues
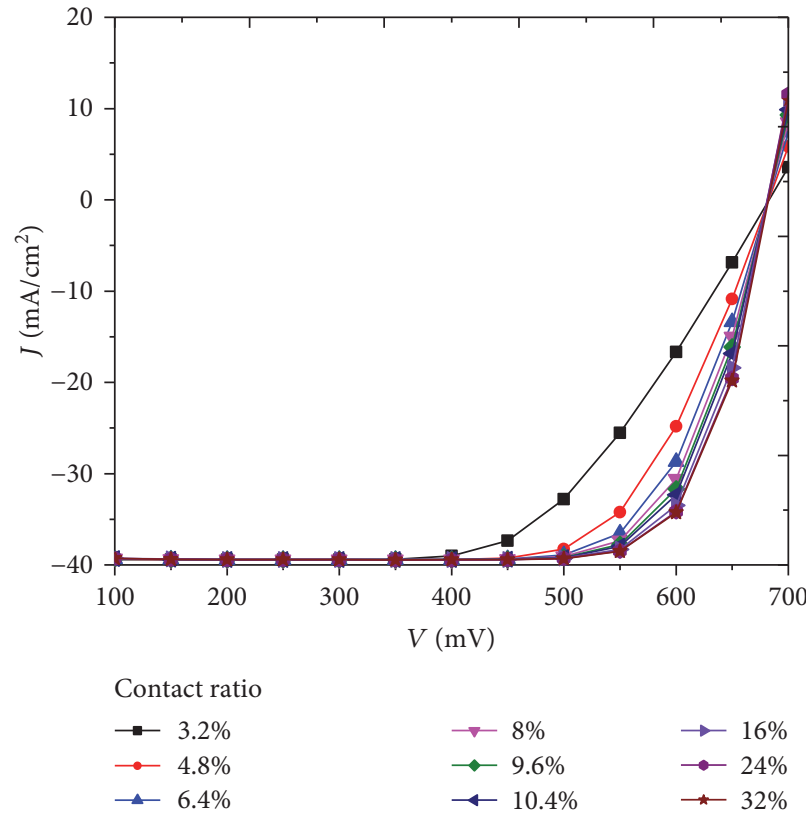

Figure 3: Light $J$ - $V$ characteristics between $100 \mathrm{mV}$ and $700 \mathrm{mV}$ at different contact ratios.

to decrease with significant change in slope. Unlike point contact, the series resistance in line contact does not stabilize after any particular value of contact ratio. This happens due to the high rate of recombination; this effect has been studied by using LBIC scan around metal lines on solar cells $[16,26,33,47,48]$ and photoluminescence [24]. The light response of these experiments measured the lowest light intensity around metal lines. This effect is responsible for electrical shading and EQE losses.

Figure 9 shows the variation of recombination and recombination current (due to the contact) with respect to contact ratio in the emitter and BSF. In both cases, there is a continuous increase (Figure 9(a)) and continuous decrease (Figure 9(b)) in curves and they do not change its behavior around any specific dimension of the width of line contact.

In the case of point contact, the recombination current due to contact in emitter decreases from $14.99 \mathrm{~mA} / \mathrm{cm}^{2}$ to $8.94 \mathrm{~mA} / \mathrm{cm}^{2}$ and in the case of line contact, the recombination current in emitter due to contact decreases from $6.46 \mathrm{~mA} / \mathrm{cm}^{2}$ to $3.76 \mathrm{~mA} / \mathrm{cm}^{2}$. In the case of point contact, the recombination current due to contact in BSF decreases from $12.65 \mathrm{~mA} / \mathrm{cm}^{2}$ to $9.49 \mathrm{~mA} / \mathrm{cm}^{2}$, and in the case of line contact, the recombination current due to contact in BSF decreases from $4.27 \mathrm{~mA} / \mathrm{cm}^{2}$ to $3.10 \mathrm{~mA} / \mathrm{cm}^{2}$. This means that the magnitude of recombination current in the line contact is less than the magnitude of recombination current in the point contact. The recombination current in the IBC solar cells calculated from Quokka is given by [49]

$$
J_{\text {rec }}=J_{0}\left(X^{1 / n}-1\right)
$$

where $J_{0}$ is the saturation current density, $X$ is the fluence, and $n$ is the ideality factor. 


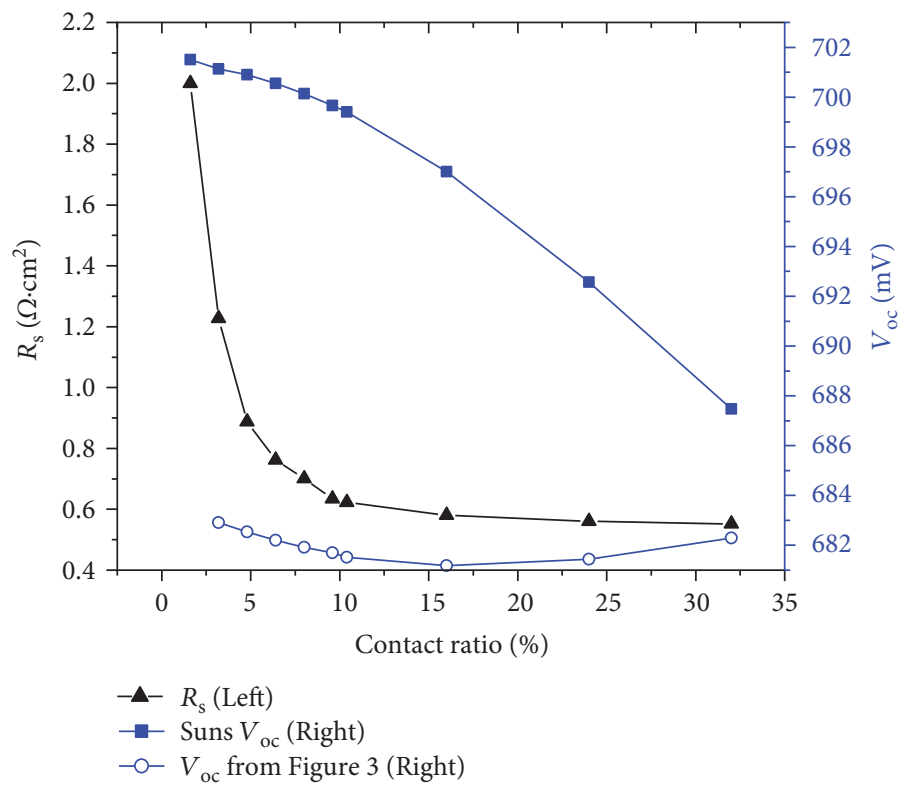

Figure 4: Variation of $R_{\mathrm{s}}$ and $V_{\mathrm{oc}}$ with respect to contact ratio.

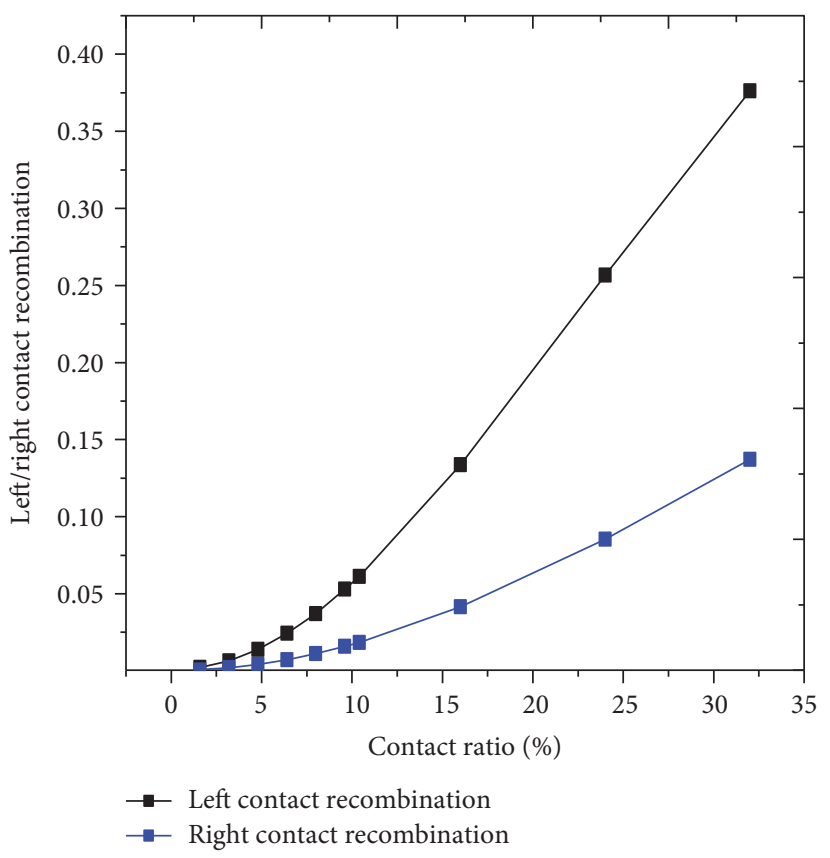

(a)

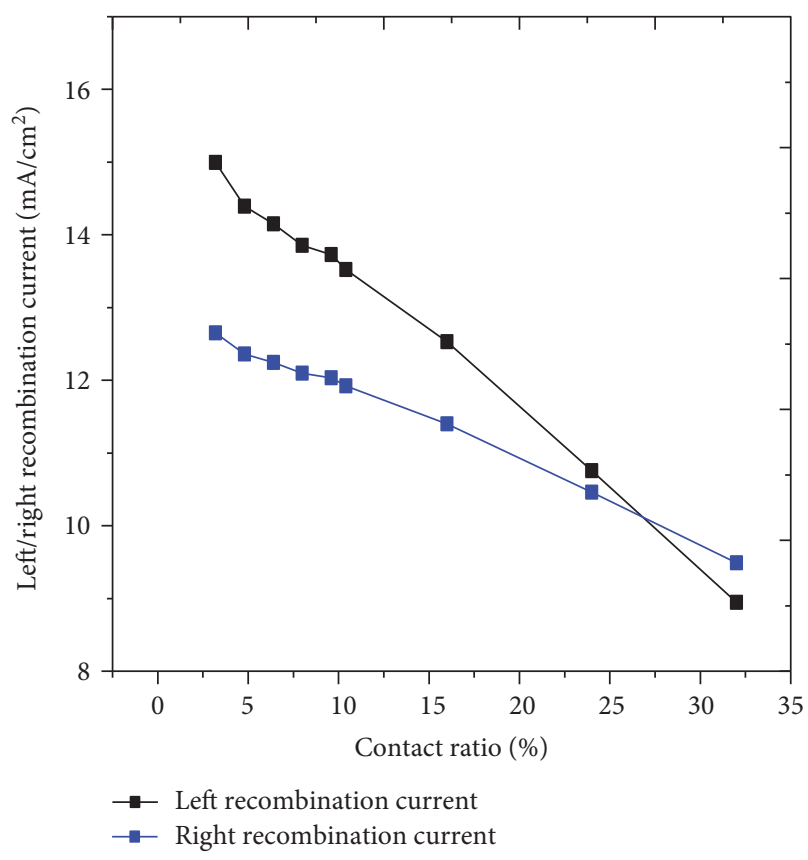

(b)

FIGURE 5: Variation of (a) left/right contact recombination with respect to contact ratio and (b) left/right contact recombination current with respect to contact ratio.

The recombination current is strongly dependent on ideality factor. The higher values of recombination current in point contact is due to the lower ideality factor.

In the case of point contact, the recombination in emitter increases from 0.002 to 0.376 and in the case of line contact, the recombination in emitter increases from 0.084 to 0.478 . In the case of point contact, the recombination in BSF, increases from 0.0018 to 0.137 and in the case of line contact, the recombination in BSF increases from 0.018 to 0.134 . The recombination in the case of line contact is concave down increasing (Figure 9(a)) and recombination in the case of point contact is concave up increasing (Figure 5(a)) which means that the recombination started taking higher values at low contact ratios in line contact. This tells us that there is more recombination in line contact than point contact.

The area covered by line and point contacts are shown in Table 2. The high recombination in the case of line contact is due to the fact that there is more area covered by line contact, 


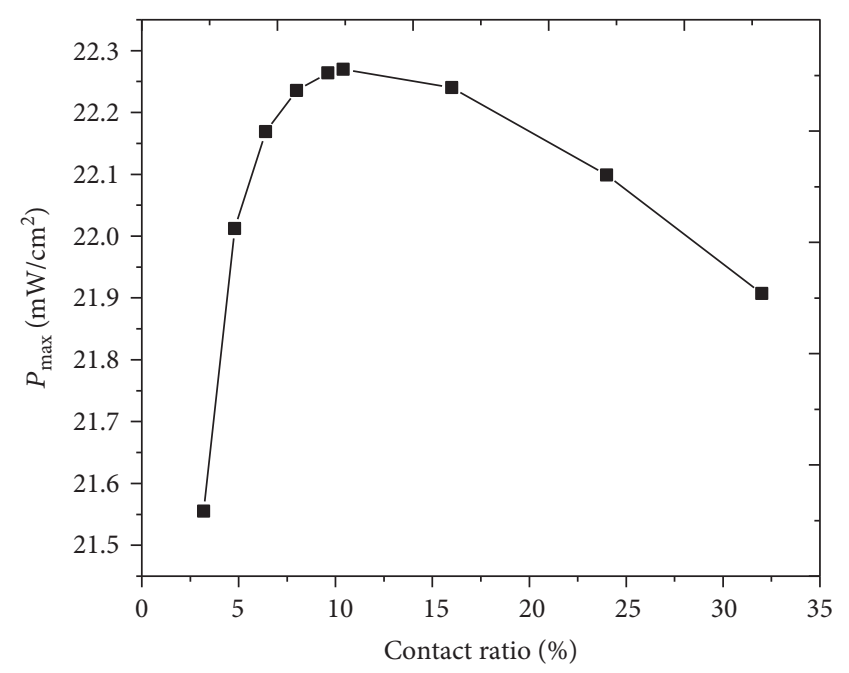

FIGURE 6: Variation of maximum power with respect to contact ratio.

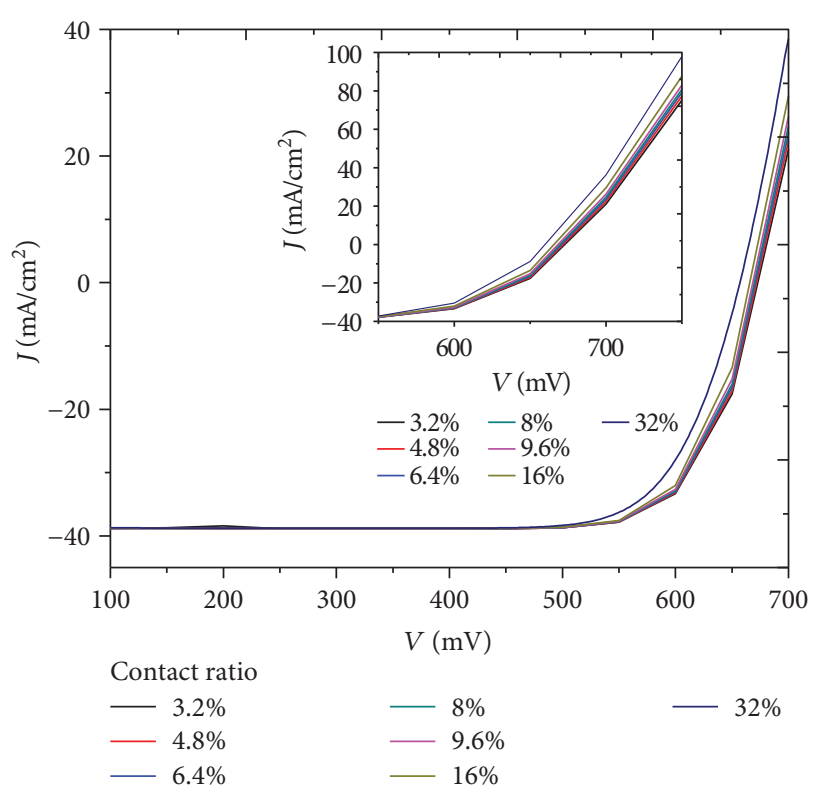

FIgURE 7: Light $J$ - $V$ at different widths of line contacts.

which increases the reverse saturation current in the contacted region $[25,26]$. This gives us the reason why most of the IBC solar cells are fabricated with point contact.

\section{Discussion}

In the fabrication of IBC solar cells, there is not much importance given to contact sizes. Most of the time, the dimensions of contacts are considered the same irrespective of the dimension of the emitter and BSF. For the exact comparison with recombination, more experimental results are required, which specifically focus on contact size. However, most of the optimization of contact sizes are done at wafer level, that is, by processing of wafer for sheet resistance measurement
[25], lifetime measurement [50], and transfer length measurement [51]. But these measurements do not relate contact sizes with cell parameters. To have better understanding of modeling, it needs more experimental result with respect to contact sizes on IBC solar cells.

The variation in recombination is still unknown and many parameters can be responsible for it. The dimensions of contact sizes cannot be solely responsible for the recombination mechanism in solar cells. The bulk defects and traps $[52,53]$ are also responsible for recombination in solar cells. The bulk defects influence the diffusion length [54], which reduces the light-induced current in solar cells especially of IBC structure.

In the high efficiency solar cells, the losses due to contacts are very less (roughly around 6\%) [16] and it can be further reduced by optimizing its dimension. There are pros and cons associated with both large and small contact sizes. Small contact size gives large Suns $V_{\mathrm{oc}}$ but high $R_{\mathrm{s}}$ reduces fill factor. Large contact size reduces $R_{\mathrm{s}}$ but at the same time it reduces Suns $V_{\mathrm{oc}}$.

In the case of point contact, maximum power shows its peak value neither at the lowest contact size/ratio nor at the highest contact size/ratio, but at some middle values, this uses the advantageous features of both low $R_{\mathrm{s}}$ and large $V_{\mathrm{oc}}$.

In the case of line contact, there is a possibility of huge shading losses especially in large area cells, but it has another advantage of high collection efficiency. The dimensions of point contacts should be optimized properly with respect to contact pitch and area; otherwise, the solar cells having line contact will behave similarly as the solar cells having point contact. To get the advantages of point contact, the contact pitch should be optimized with respect to the diffusion length $[13]$ and emitter coverage $[15,37]$ because this affects the lateral carrier transport.

There is always a compromising situation between charge collection and contact resistance. The current transfer length proposed by Shockley et al. [55] can provide great help in the optimization of contact size. The current transfer length is calculated using [18]

$$
L_{\mathrm{T}}=\sqrt{\frac{\rho_{\mathrm{c}}}{R_{\mathrm{sh}}}},
$$

where $L_{\mathrm{T}}$ is the transfer length, $\rho_{\mathrm{c}}$ is the contact resistivity, and $R_{\mathrm{sh}}$ is the sheet resistance.

Although current transfer length gives the idea of minimum contact size, it does not give the exact required size because this measurement is done at wafer level.

The area covered by the contact can also give good approximation to guess high efficiency $[25,26]$. It is dubious to simulate solar cells with respect to area of contacts because different shapes like circle, square, rectangle, and triangle can have the same area but they will have different contact resistance and sheet resistance and simulation of solar cells may show the same results with respect to the same area of different shapes. There is a possibility of losses like error in specific contact resistance [56] and high ideality factor [57] with rectangular and square shapes. That is why one should avoid rectangular and square shapes as point contact. 


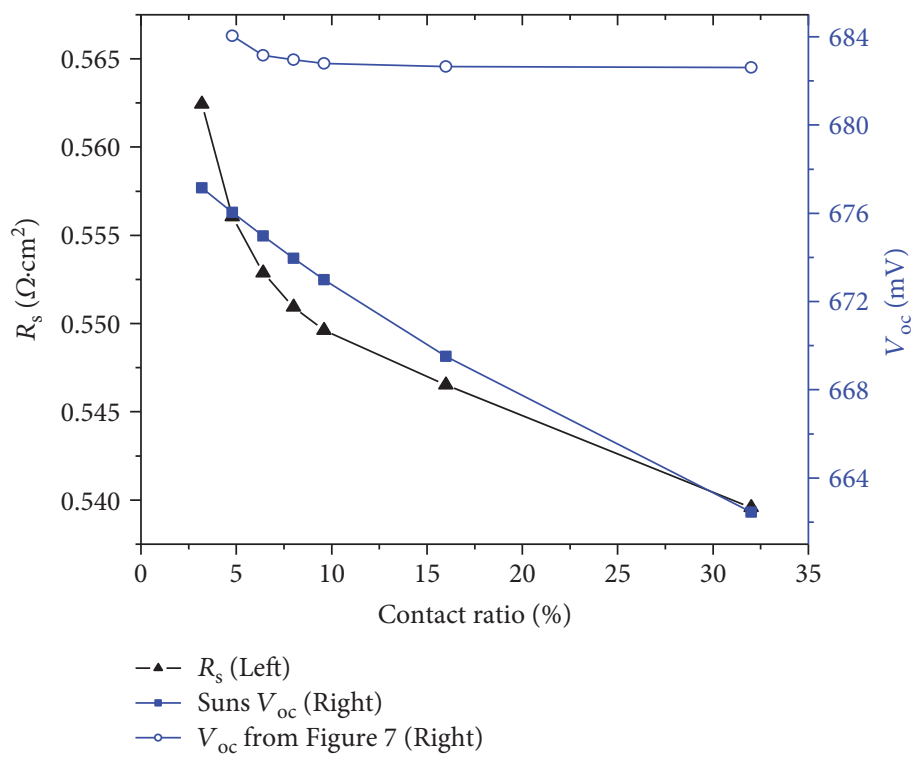

Figure 8: Variation of $R_{\mathrm{s}}$ and $V_{\mathrm{oc}}$ with respect to contact ratio.

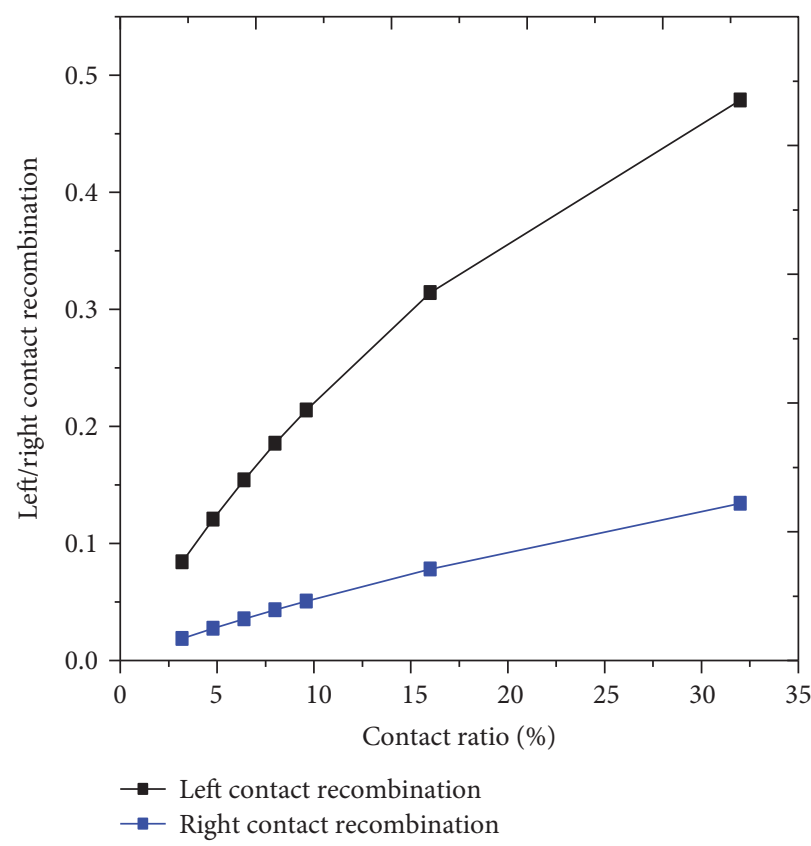

(a)

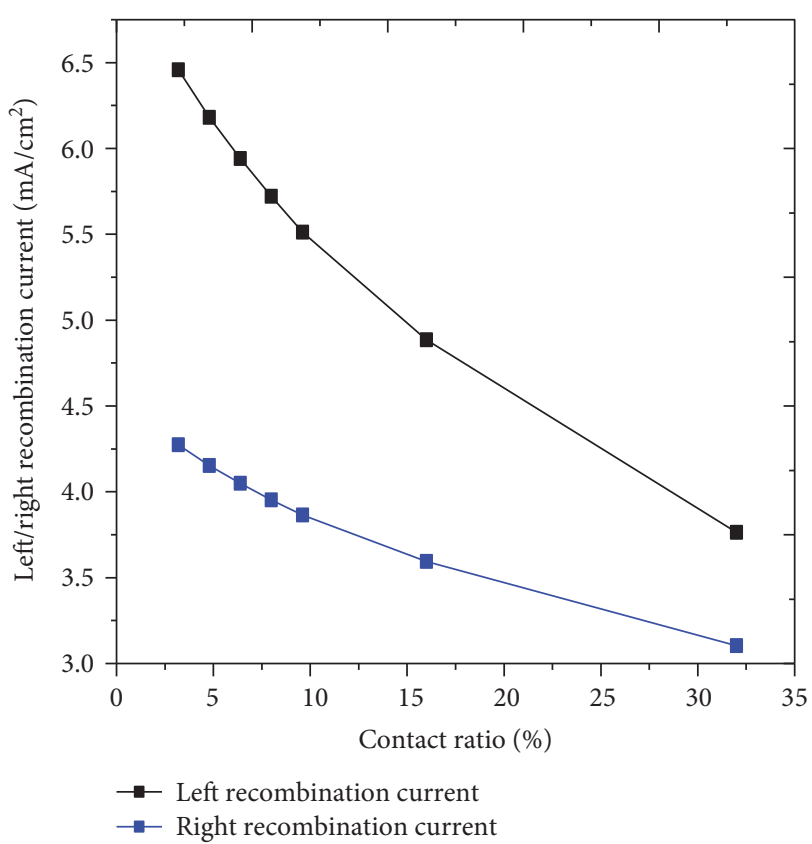

(b)

FIGURE 9: Variation of (a) left/right contact recombination with respect to contact ratio and (b) left/right contact recombination current with respect to contact ratio.

\section{Conclusion}

Simulation results were presented with respect to line and point contacts on unit cell of IBC solar cells. Light $J-V$ characteristics were different for both cases. There was a continuous decrease in series resistance with respect to contact ratio in the case of line contact but with point contact series, resistance stabilizes above $10 \%$ of contact ratio. There was a change observed in maximum power calculation around $10 \%$ of contact ratio, with point contact. There is no hard and fast rule in the selection of contact size whether it should be as minimum as possible or as maximum as possible. There is always a compromise between low $R_{\mathrm{s}}$ and high $V_{\mathrm{oc}}$ in the optimization of contact size but it can be optimized with respect to maximum power.

In the case of line contact, there was not much variation observed with respect to the size of line contact. There was a continuous decrease in series resistance and Suns $V_{\text {oc }}$ with 
TABle 2: Percentage area covered by line and point contact with respect to contact size.

\begin{tabular}{lcc}
\hline $\begin{array}{l}\text { Contact } \\
\text { size }(\mu \mathrm{m})\end{array}$ & $\begin{array}{c}\text { Percentage (\%) area } \\
\text { covered by point contact }\end{array}$ & $\begin{array}{c}\text { Percentage (\%) area } \\
\text { covered by line contact }\end{array}$ \\
\hline 8 & 0.10048 & 3.2 \\
12 & 0.22608 & 4.8 \\
16 & 0.40192 & 6.4 \\
20 & 0.628 & 8 \\
24 & 0.90432 & 9.6 \\
26 & 1.06132 & 10.4 \\
40 & 2.512 & 16 \\
60 & 5.652 & 24 \\
80 & 10.048 & 32 \\
\hline
\end{tabular}

respect to the contact ratio. Moreover, there was a negligible increase in $V_{\text {oc }}$ (calculated from light $J-V$ ) with line contact.

Although the behavior of recombination and recombination current due to contact were the same in both cases of point and line contact, the point contact showed small variation below $10 \%$ of contact ratio. The comparison of simulation results of point and line contact showed that the magnitude of recombination was lower in the case of point contact.

Our simulation results shows that with the use of point contact and at around $10 \%$ of contact ratio, the IBC structure can achieve optimum cell efficiency. However, to further reduce the effect of series resistance, one can increase contact ratio maximum up to $15 \%$ to overcome the challenges of fabrication and cost.

\section{Conflicts of Interest}

The authors declare that there is no conflict of interest regarding the publication of this paper.

\section{References}

[1] K. Yoshikawa, H. Kawasaki, W. Yoshida et al., "Silicon heterojunction solar cell with interdigitated back contacts for a photoconversion efficiency over 26\%," Nature Energy, vol. 2, article 17032, 2017.

[2] K. Masuko, M. Shigematsu, T. Hashiguchi et al., "Achievement of more than $25 \%$ conversion efficiency with crystalline silicon heterojunction solar cell," IEEE Journal of Photovoltaics, vol. 4, no. 6, pp. 1433-1435, 2014.

[3] J. Nakamura, N. Asano, T. Hieda, C. Okamoto, H. Katayama, and K. Nakamura, "Development of heterojunction back contact Si solar cells," IEEE Journal of Photovoltaics, vol. 4, no. 6, pp. 1491-1495, 2014.

[4] D. Smith, P. Cousins, S. Westerberg et al., "Toward the practical limits of silicon solar cells," IEEE Journal of Photovoltaics, vol. 4, no. 6, pp. 1465-1495, 2014.

[5] E. Franklin, K. Fong, K. McIntosh et al., "Fabrication and characterization of a $24.4 \%$ efficiency IBC cell, 29th European Photovoltaic Solar Energy, pp. 666-671, 2014," Progress in Photovoltaics: Research and Applications, vol. 24, no. 4, pp. 411-427, 2014.
[6] C. Reichel, F. Granek, M. Hermle, and S. W. Glunz, "Back-contacted back-junction n-type silicon solar cells featuring an insulating thin film for decoupling charge carrier collection and metallization geometry," Progress in Photovoltaics: Research and Applications, vol. 21, pp. 10631076, 2013.

[7] M. Aleman, J. Das, T. Janssens et al., "Development and integration of a high efficiency baseline leading to $23 \%$ IBC cells," Energy Procedia, vol. 27, pp. 638-645, 2012.

[8] D. Smith, P. J. Cousins, A. Masad et al., "Generation III high efficiency lower cost technology: transition to full scale manufacturing," in 38th IEEE Photovoltaics Specialists Conference, Austin, TX, USA, 2012.

[9] C. B. Mo, S. J. Park, Y. J. Kim et al., "High efficiency back contact solar cell via ion implantation," in 27th European Photovoltaic Solar Energy Conference, September 2012.

[10] https://www.pv-tech.org/news/trina-solar-achieves-24.13-con version-efficiency-for-ibc-solar-cell.

[11] http://www.solarserver.com/solar-magazine/solar-news/archi ve-2013/2013/kw33/bosch-isfh-produce-221-efficient-c-si-sol ar-pv-cell.html.

[12] P. J. Verlinden, R. M. Swanson, and R. A. Crane, "7000 highefficiency cells for a dream," Progress in Photovoltaics: Research and Applications, vol. 2, pp. 143-152, 1994.

[13] F. Granek, M. Hermle, D. M. Huljic, O. S. Wittman, and S. W. Glunz, "Enhanced lateral current transport via the front $\mathrm{N}^{+}$ diffused layer of n-type high-efficiency back-junction backcontact silicon solar cells," Progress in Photovoltaics: Research and Applications, vol. 17, pp. 47-56, 2009.

[14] T. Desrues, S. de Vecchi, G. Alonzo, D. Munoz, and P.-J. Ribeyron, "Influence of the emitter coverage on interdigitated back contact (IBC) silicon heterojunction (SHJ) solar cells," in 40th IEEE Photovoltaics Specialists Conference, pp. 857-861, Denver, CO, USA, June 2014.

[15] M. Hermle, F. Granek, O. S. Wittman, and S. W. Glunz, "Shading effects in back-junction back-contacted silicon solar cells," in 33rd IEEE Photovoltaics Specialists Conference, San Diego, CA, USA, May 2008.

[16] F. Granek, High-Efficiency Back-Contact Back-Junction Silicon Solar Cells, Chapter 6.5, [Ph. D. Thesis], Fraunhofer Institut für Solare Energiesysteme (ISE), 2009.

[17] P. J. Verlinden, M. Aleman, N. Posthuma et al., "Simple power-loss analysis method for high-efficiency interdigitated back contact (IBC) silicon solar cells," Solar Energy Materials and Solar Cells, vol. 106, pp. 37-41, 2012.

[18] D. L. Meier and D. K. Schroder, "Contact resistance: its measurement and relative importance to power loss in a solar cell," IEEE Transactions on Electron Devices, vol. ED-31, no. 5, pp. 647-653, 1984.

[19] M. K. M. Desa, M. Y. Sulaiman, K. Sopian, S. Sepeai, A. W. Azhari, and S. H. Zaidi, "Optimization of p-type screen printed interdigitated back contact silicon solar cell with aluminum back surface field," International Journal of Engineering and Technology, vol. 14, no. 2, pp. 69-80, 2014.

[20] P. Procel, M. Zanuccoli, V. Maccaronio et al., "Numerical simulation of the impact of design parameters on the performance of back-contact back-junction solar cell," Journal of Computation Electron, vol. 15, pp. 260-268, 2016.

[21] M. Lu, U. Das, S. Bowden, S. Hegedus, and R. Birkmire, “Optimization of interdigitated back contact silicon heterojunction solar cells by two-dimensional numerical simulation," in 34 th 
IEEE Photovoltaics Specialists Conference, pp. 1034-1038, Philadelphia, PA, USA, June 2009.

[22] A. R. Burgers, I. Cesar, N. Guillevin et al., "Mercury: a back junction back contact cell with novel design for high efficiency and simplified processing," in SNEC 8th International Photovoltaic Power Generation Conference, Shanghai, China, 2014.

[23] M. Padilla, B. Michl, C. Reichel et al., "Characterizing local contact resistances of interdigitated back contact silicon solar cells," in 29th European Photovoltaic Solar Energy Conference, Amsterdam, The Netherlands, September 2014.

[24] I. Cesar, N. Guillevin, A. R. Burgers et al., "Mercury: a novel design for a back junction back contact cell with front floating emitter for high efficiency and simplified processing," in 29th European Photovoltaic Solar Energy Conference, Amsterdam, the Netherlands, September 2014.

[25] K. Fong, K. Teng, K. R. McIntosh et al., "Optimisation of N+ diffusion and contact size of IBC solar cells," in 28th European Photovoltaic Solar Energy Conference, pp. 851-855, 2012.

[26] C. Reichel, M. Reusch, F. Granek, M. Hermle, and S. W. Glunz, "Decoupling charge carrier collection and metallization geometry of back-contacted back-junction silicon solar cells by using insulating thin films," in 35th IEEE Photovoltaics Specialists Conference, pp. 1034-1038, Honolulu, HI, USA, June 2010.

[27] A. Fell, K. C. Fong, K. R. McIntosh, E. Franklin, and A. W. Blakers, "3-D simulation of interdigitated-back-contact silicon solar cells with Quokka including perimeter losses," IEEE Journal of Photovoltaics, vol. 4, no. 4, pp. 1040-1045, 2014.

[28] G. Galbaiti, V. D. Mihailetchi, A. Halm, H. Chu, and R. Kopecek, "Large area IBC ZEBRA solar cells in pilot production: the results of FP7 Hercules project," in 33rd European Photovoltaic Solar Energy Conference, 2017.

[29] A. Fell, "A free and fast 3D/2D solar cell simulator featuring conductive boundary and quasi neutral approximations," IEEE Transactions on Electron Devices, vol. 60, no. 2, pp. 733-738, 2012.

[30] A. Fell, K. R. McIntosch, M. Abbott, and D. Walter, "Quokka version 2: a selective surface doping, luminescence modeling and data fitting," in 23rd International Photovoltaic Science and engineering Conference, Taipei, 2013.

[31] C. Ulzhöfer, B. Wolpensinger, and J. Schmidt, "Understanding the lifetime evolution in n-type multicrystalline silicon during phosphorous gettering and hydrogenation," in 23rd European Photovoltaic Solar Energy Conference, pp. 1051-1056, Valencia, Spain, September 2008.

[32] S. Castellanos, M. Kivambe, M. A. Jensen et al., "Exceeding 3 $m s$ minority carrier lifetime in $n$-type non-contact crucible silicon," Energy Procedia, vol. 92, pp. 779-784, 2016.

[33] C. Gong, E. V. Kerschaver, J. Robbelein et al., "Screen-printed aluminum-alloyed $\mathrm{p}^{+}$emitter on high-efficiency n-type interdigitated back-contact silicon solar cells," in IEEE Electron Device Letters, vol. 31, no. 6, pp. 576-578, April 2010.

[34] R. Bock, S. Mau, J. Schmidt, and R. Brendel, "Back-junction back-contact n-type silicon solar cells with screen-printed aluminum-alloyed emitter," Applied Physics Letters, vol. 96, article 263507, 2010.

[35] R. Muller, C. Reichel, J. Benick, and M. Hemerle, "Ion implantation for all-alumina IBC solar cells with floating emitter," Energy Procedia, vol. 55, pp. 265-271, 2014.

[36] R. Müller, J. Benick, N. Bateman et al., "Evaluation of implantation annealing for highly-doped selective boron emitters suitable for screen-printed contacts," Solar Energy Materials and Solar Cells, vol. 120, pp. 431-435, 2014.

[37] V. Mertens, S. Bordihn, Y. Larionova, N. P. Harder, and R. Brendel, "The buried emitter solar cell concept: interdigitated back-junction structure with virtually $100 \%$ emitter coverage of the cell area," in 24th European Photovoltaic Solar Energy Conference, pp. 934-936, Hamburg, Germany, September 2009.

[38] http://www.pveducation.org/.

[39] D. K. Schroder and D. L. Meier, "Solar cell contact resistance-a review," IEEE Transactions on Electron Devices, vol. 31, no. 5, pp. 637-647, 1984.

[40] M. Dadu, A. Kapoor, and K. N. Tripathi, "Effect of operating current dependent series resistance on the fill factor of a solar cell," Solar Energy Materials and Solar Cells, vol. 71, pp. 213218, 2002.

[41] G. J. M. Janssen, Y. Wu, K. C. J. J. Tool, I. G. Romijn, and A. Fell, "Extraction of recombination properties from lifetime data," Energy Procedia, vol. 92, pp. 88-95, 2016.

[42] G. Trentadue, D. Pavanello, E. Salis, M. Field, and H. Müllejans, "Determination of internal series resistance of PV devices: repeatability and uncertainty," Measurement Science and Technology, vol. 27, article 055005, 2016.

[43] A. Hovinen, "Fitting of the solar cell IV-curve to the two diode model," Physica Scripta, IOP Science, vol. T54, pp. 175-176, 1994.

[44] B. Sopori, V. Budhraja, P. Rupnowski et al., "Defect clusters in multicrystalline silicon: their nature and influence on the solar cell performance," in 34th IEEE Photovoltaics Specialists Conference, pp. 1969-1974, Philadelphia, PA, USA, June 2009.

[45] D. Carrió, P. Ortega, I. Martin et al., "Rear contact pattern optimization based on 3D simulations for IBC solar cells with point-like doped contacts," Energy Procedia, vol. 55, pp. 47-52, 2014.

[46] G. Heiser, A. G. Aberle, S. R. Wenham, and M. A. Green, "Two-dimensional numerical simulations of high-efficiency silicon solar cells," Microelectronics, vol. 26, pp. 273-286, 1995.

[47] P. Engelhart, N. P. Harder, A. Merkle, R. Grischke, R. Mayer, and R. Brendel, "Rise: 21.5\% efficient back junction silicon solar cells with laser technology as a key processing tool," in IEEE 4th World Conference on Photovoltaic Energy Conversion, pp. 900-904, Waikoloa, HI, USA, May 2006.

[48] C. Reichel, F. Granek, M. Hermle, and S. W. Glunz, "Enhanced current collection in back-contacted back-junction Si solar cells by overcompensating a boron emitter with a phosphorous base-type doping," Physica Status Solidi A, vol. 207, no. 8, pp. 1978-1981, 2010.

[49] A. Fell, D. Walter, S. Kluska, E. Franklin, and K. Weber, "Determination of injection dependent recombination properties of locally processed surface regions," Energy Procedia, vol. 38, pp. 22-31, 2013.

[50] H. Mäckel and K. Varner, "On the determination of the emitter saturation current density from lifetime measurements of silicon devices," Progress in Photovoltaics: Research and Applications, vol. 21, pp. 850-866, 2013.

[51] D. K. Schroder, Semiconductor Material and Device Characterization, Chapter-3, 3rd edition, 2006.

[52] B. Sopori, "Silicon solar-cell processing for minimizing the influence of impurities and defects," Journal of Electronic Materials, vol. 31, no. 10, pp. 972-980, 2002. 
[53] H. E. Ghitani and S. Martinuzzi, "Influence of dislocations on electrical properties of large grained polycrystalline silicon cells. I. Model," Journal of Applied Physics, vol. 66, pp. 17171722, 1989.

[54] B. L. Sopori, R. W. Gurtler, and I. A. Lesk, "Effect of optical beam size on diffusion length measured by the surface photo-voltage method," Solid State Electronics, vol. 23, pp. 139-142, 1979.

[55] W. Shockley, A. Goetzberger, and R. M. Scarlett, "Research and investigation of inverse epitaxial UHF power transitors," in AFAL-TDR-64-207, Air Force Avionics Lab, 1964.

[56] A. S. Holland, Y. Pan, M. Saleh, N. Alnassar, and S. Luong, "Circular test structures for determining the specific contact resistance of ohmic contacts," Facta Universitatis, Series: Electronics and Energetics, vol. 30, no. 3, pp. 313-326, 2017.

[57] I. A. Amatalo, N. E. Makori, J. Maera, D. Wamawangi, and P. M. Karimi, "Effect of metal-semiconductor contact geometry on electrical properties of $\mathrm{Al} / \mathrm{ZnSe}$ thin films," Microelectronics and Solid State Electronics, vol. 3, no. 1, pp. 11-14, 2014. 

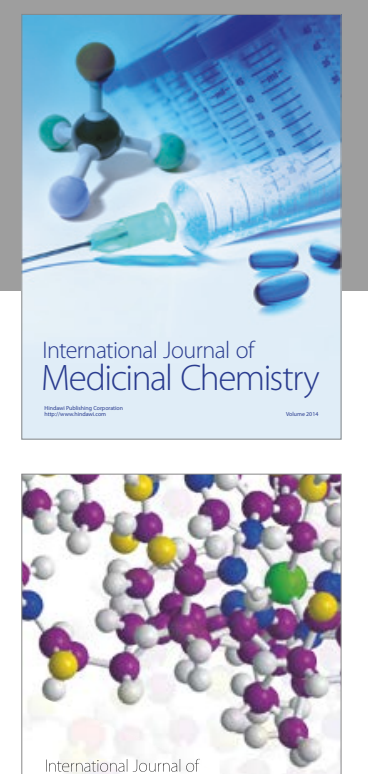

Carbohydrate Chemistry

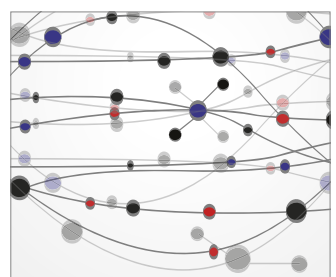

The Scientific World Journal
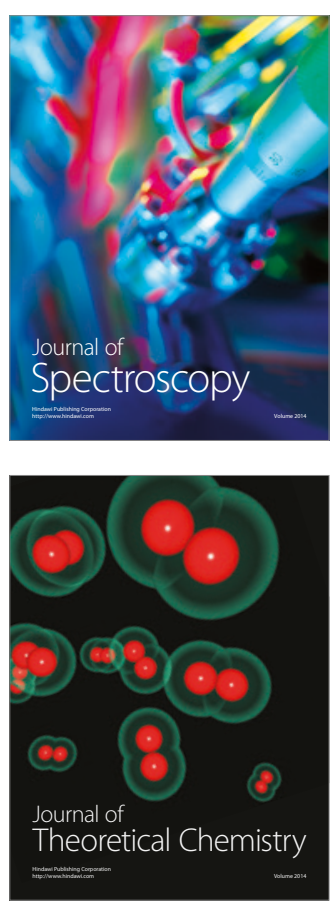
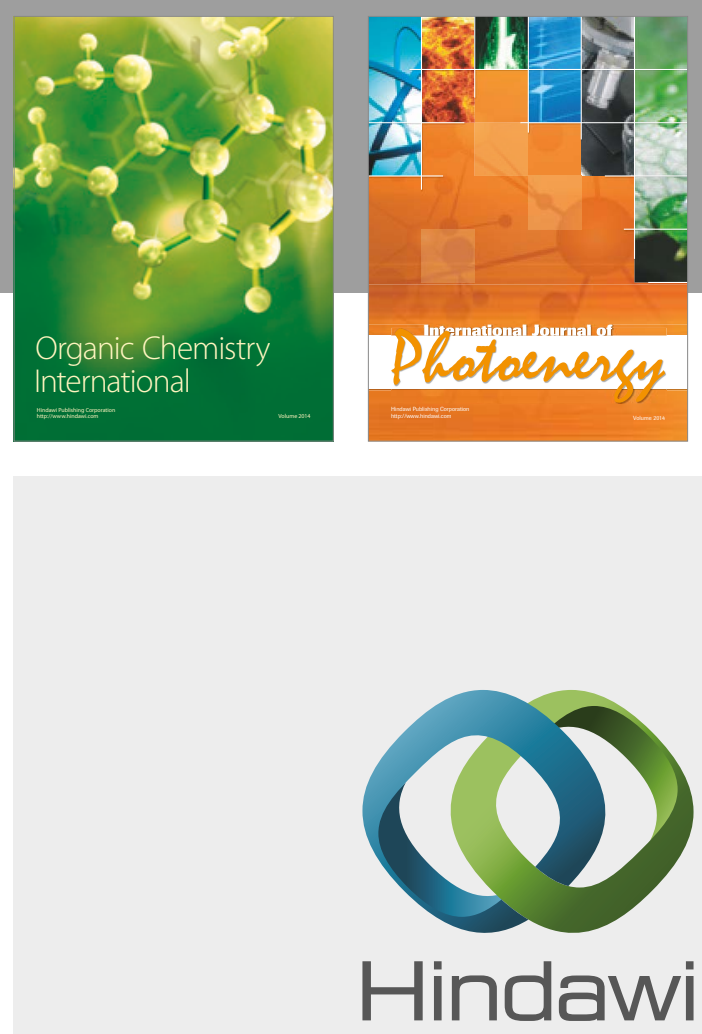

Submit your manuscripts at

https://www.hindawi.com

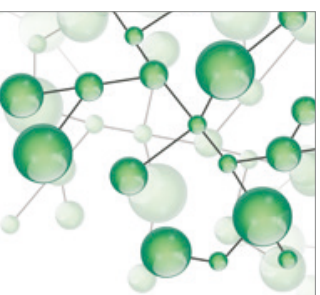

International Journal of

Inorganic Chemistry

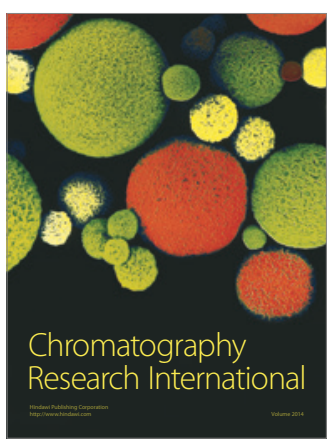

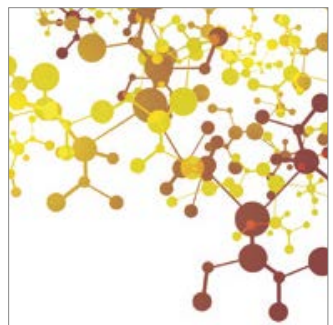

Applied Chemistry
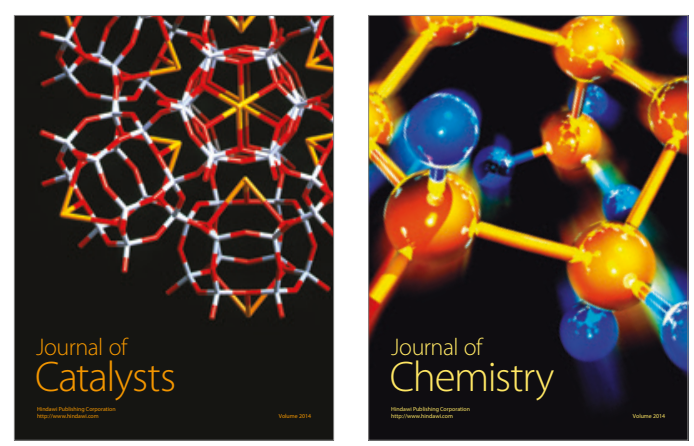
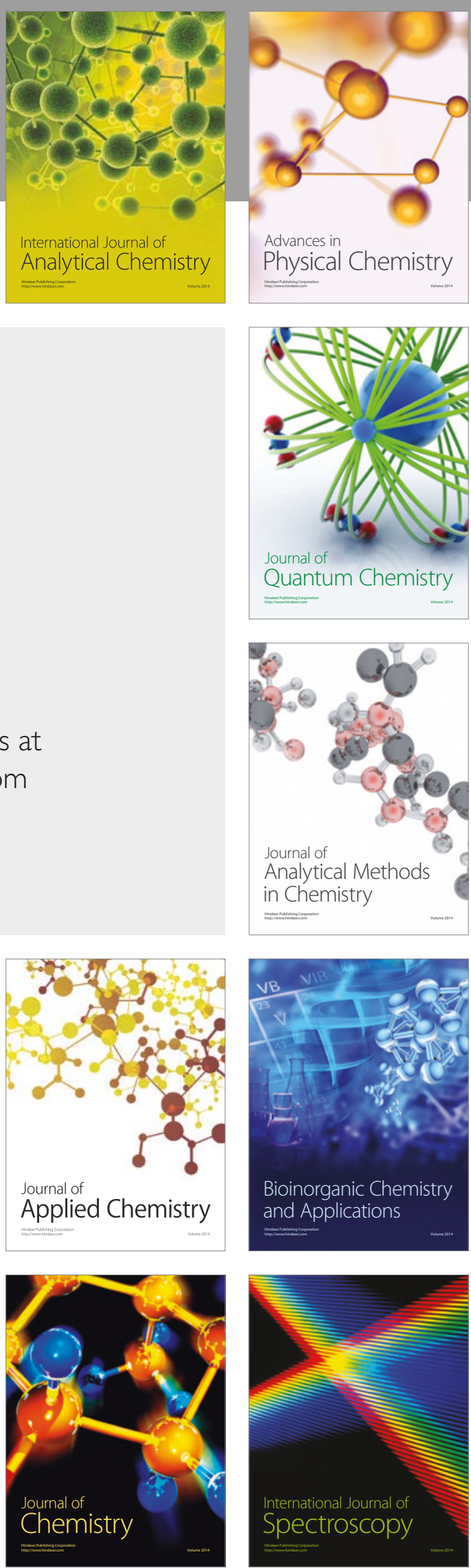